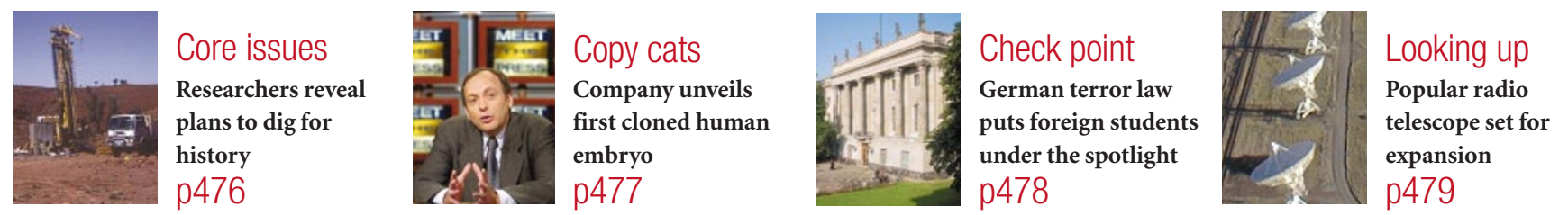

\title{
Proposed budget cuts threaten to short-circuit Grid network
}

\section{Declan Butler, Paris}

Computer scientists fear that plans to redraw the budget for the next five-year Framework research programme run by the European Union (EU) will cripple efforts to develop 'Grid' technology. The Grid aims to create unprecedented computing power by linking individual machines over highspeed networks using advanced software known as middleware.

Under the sixth Framework programme, which is due to run from 2002 to 2006 , EU research commissioner Philippe Busquin had proposed spending 900 million euros (US\$793 million) of the programme's 17.5billion-euro budget on infrastructure projects, including the Grid. The European Parliament has already called for changes, requesting that 350 million euros, including the money for the Grid, be transferred to the 'information society' budget, and asking for a further cut of 75 million euros to free up money for research on health, energy, transport and the environment (see Nature 414, 386;2001).

In a modified proposal, the European Commission produced a revised figure of 800 million euros for infrastructure. But Britain, Spain and Sweden are pushing for a figure of 500 million euros, with no transfer of money to other budget lines. The position of the other countries is unclear, although Italy, Austria, Finland, Portugal and Belgium seem ready to accept the 800-million figure.

Cutting the infrastructure budget to 500 million euros could place the Grid in jeopardy. Around 350 million euros of Busquin's original budget was to have been earmarked for high-speed networks and Grid projects. And whatever budget is finally agreed, 150 million euros is expected to be allocated for upgrading and running Géant - a panEuropean research network that will allow Europe to keep pace with planned upgrades in the United States. That would leave projects to develop Grid software competing in the reduced pool with everything from oceanography to bioinformatics.

If so, Europe's Grid efforts would go right back to square one, says David Williams, who coordinates relations with the EU for CERN,

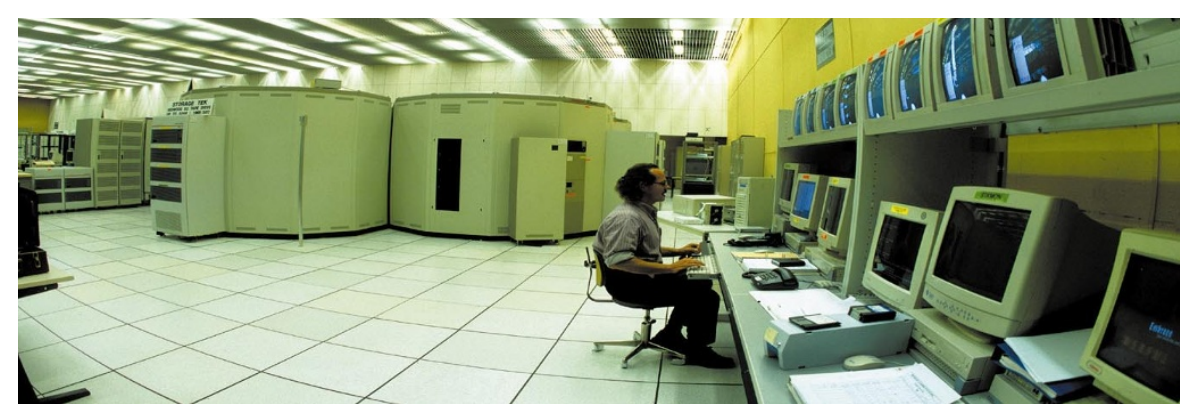

Data dilemma: many European facilities need Framework funds to keep abreast of high-tech advances.

the European laboratory for particle physics near Geneva: "There is a strong risk that the intricacies of the decision-making process will cause severe collateral damage."

But even if the budget is slashed, some commission officials are optimistic that funding for Grid projects may be found from other parts of the Framework programme.

CERN is relying on the EU's Grid activities to ensure that it will be able to handle the 7 petabytes $\left(10^{15}\right.$ bytes $)$ of data that its Large Hadron Collider will generate every year when it comes online in 2006. Analysing these data will require a thousand times more computing power than CERN can deliver.
Scientists in other areas hoping for infrastructure money are similarly distressed by the signs that it is to be cut. "The impact would be disastrous," says an official at the European Bioinformatics Institute (EBI) near Cambridge. "I believe that what we do at the EBI has to be done at the European level, and if you kill that, then there just isn't any alternative funding mechanism."

A large cut to the infrastructure budget would also be a major blow to Busquin's plans to create a 'European Research Area' (see Nature 413, 768-770;2001). Support for European-level infrastructure is one of the cornerstones of the proposal.

\section{Concern raised for missing biologist}

Alison Abbott

Structural biologists are in shock following the disappearance of Don Wiley, one of the leading figures in the field. As Nature went to

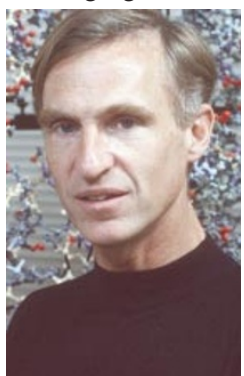

Wiley: a possible Nobel candidate. press, more than a week after Wiley's car was found abandoned near Memphis on a bridge over the Mississippi river, the FBI was still investigating.

A professor of biochemistry and biophysics at Harvard University, Wiley has been seen as a candidate for a Nobel prize. He won a 1995 Lasker award for his resolution of the structure of the two classes of major histocompatibility proteins. These proteins bind to foreign proteins, alerting the immune system to mount a response. Wiley's work opened up new vistas in immunology.

His other key work has been on the haemagglutinin protein of the influenza virus. Wiley's analyses led to the understanding of how the virus fuses with host-cell membranes. His further work on other viruses suggests the mechanism may be general.

Wiley was last seen leaving a dinner following a meeting of the scientific advisory board of St Jude Children's Research Hospital in Memphis, where he is said to have been in good spirits. 